\title{
Willingness to Pay for Improved Operations and Maintenance Services of Gravity-Fed Water Schemes in Idjwi Island (Democratic Republic of the Congo)
}

\author{
Ruben Jimenez-Redal ${ }^{1, *}$, Germán Arana-Landín ${ }^{2}$ (D), Beñat Landeta ${ }^{1}$ (D) and Jaime Larumbe ${ }^{3}$ \\ 1 Department of Management, Faculty of Engineering, University of the Basque Country EHU/UPV, Pl IT \\ Quevedo 1, 48013 Bilbao, Spain; benat.landeta@ehu.eus \\ 2 Department of Management, Faculty of Engineering, University of the Basque Country EHU/UPV, Pl Europa \\ 1, 20018 San Sebastian, Spain; g.arana@ehu.eus \\ 3 Department of Project Engineering, Faculty of Engineering, University of the Basque Country EHU/UPV, Pl \\ IT Quevedo 1, 48013 Bilbao, Spain; jaime.larumbe@ehu.eus \\ * Correspondence: ruben.jimenez@ehu.eus; Tel.: +34-946-014-376
}

check for

updates

Citation: Jimenez-Redal, R.;

Arana-Landín, G.; Landeta, B.;

Larumbe, J. Willingness to Pay for

Improved Operations and

Maintenance Services of Gravity-Fed Water Schemes in Idjwi Island

(Democratic Republic of the Congo).

Water 2021, 13, 1050. https://

doi.org/10.3390/w13081050

Academic Editor: Francesco De Paola

Received: 2 March 2021

Accepted: 8 April 2021

Published: 11 April 2021

Publisher's Note: MDPI stays neutral with regard to jurisdictional claims in published maps and institutional affiliations.

Copyright: (c) 2021 by the authors. Licensee MDPI, Basel, Switzerland. This article is an open access article distributed under the terms and conditions of the Creative Commons Attribution (CC BY) license (https:// creativecommons.org/licenses/by/ $4.0 /)$.

\begin{abstract}
Developing understanding of the economic value that communities ascribe to improved operations and maintenance (O\&M) services has emerged as a key factor in achieving financial sustainability for rural water systems. The present study elicits household willingness to pay (WTP) for improved O\&M services in eight gravity-fed water schemes in Idjwi Island (Democratic Republic of the Congo, DRC). A contingent valuation survey was implemented through an open-ended format questionnaire to 1105 heads of household and a log-linear regression model was employed to assess the factors influencing higher values. Findings show an average willingness to pay of 327 Congolese Francs (CDF) per month and 36 CDF per bucket. Results also indicate a significant WTP differential among studied schemes. The analysis of the conditioning factors reveals that the level of excludability, the participation in management meetings and the time employed in fetching water from an improved source are contingent with their WTP. The findings of this study are important for development agents trying to establish acceptable, affordable and practicable tariffs that help finance reliable rural water systems in Idjwi.
\end{abstract}

Keywords: willingness to pay WTP; financial sustainability; water tariffs; gravity-fed water schemes; Idjwi Island; DRC

\section{Introduction}

Inadequate financing of rural water systems O\&M services has become a major barrier for the provision of sustainable water services in Sub-Saharan Africa [1,2]. Although remarkable progress has been achieved in recent years increasing water service coverage to previously unserved communities [3-5] this has not translated into reliable service delivery [6-8]. In fact, a 2018 UNICEF report on average rural water supply sector functionality rates indicates that around $40 \%$ of water points in rural communities become non-functional by the 10th year after installation [9].

In this context, current development efforts have focused on providing people with universal and equitable access to safe, affordable and reliable drinking water for all [10] under the guidance of the SDG target 6.1 [11] and the framework of the human right to water and sanitation [12]. Achieving these goals require a thorough understanding of the conditions that enable long-term functionality of rural water systems [13].

In the last two decades the national water policies of many Sub-Saharan countries have relied on community-based management (CBM) as the prevalent model for managing rural water systems $[1,14,15]$. The CBM model highlights the financial responsibility of the community to effectively finance the recovery of O\&M costs, major repairs, rehabilitation and the long-term capital replacement work [16]. Despite the support of key development 
players as international donors, implementing agencies and governments $[17,18]$ recent scrutiny of the long-term functionality of rural water supply underlines weaknesses of the CBM model [19-21] and calls for improvements in the financial model. Similarly, a number of studies assessing rural water financing challenges in Sub-Saharan Africa suggest that a high proportion of communities struggle to establish and maintain a system for collecting user fees and raise the required funds for sustainable O\&M cost recovery [22,23].

Under the CBM model, communities are often expected to raise sums which are unacceptable by many members, unaffordable by vulnerable groups or impracticable on a regular basis as it disassociates from productive seasons-based income [16,24].

Carter, Herrera and several other authors $[15,16,21,25-27]$ have underlined the urgency for a new model where cost-sharing arrangements between communities and development agencies could facilitate reliable service provision. Further, international organisations $[9,28,29]$ advocate for an increase in external financial support to complement user contributions and ensure the financial viability of the projects. The aim of the new model is a partial recovery of O\&M costs through user tariffs while transfers from donors would cover major repairs, rehabilitation and replacements.

In this regard, the UNICEF 2018 rural water sector evaluation report emphasized the need for a better understanding of household preferences in the form of WTP. The report finds that an improved understanding of users' willingness to pay will assist development agents on establishing appropriate and affordable tariffs which translates into sustainable O\&M cost recovery [30-32].

With this in mind, the present study evaluates WTP for O\&M services in eight water schemes in Idjwi Island (DRC). To the extent of the authors' knowledge, there is no reported study on household demand for improved water services in this region. The implementing agencies in charge of the water infrastructures in the island for the last 15 years, ICLI and RAIDCO, grew concerned about the acute financial challenges for reliable service provision. These agencies intend to set with the communities new tariffs that can be acceptable, affordable, equitable and practicable. For this purpose, it is necessary a thorough understanding of the households WTP for O\&M services. This is the goal of the present investigation.

\section{Materials and Methods}

\subsection{Study Area}

This study has been undertaken in Idjwi, an island located in Lake Kivu, DRC: only two kilometres from the border with Rwanda (Figure 1). Idjwi Island lies between latitudes $01^{\circ} 55^{\prime}$ and $02^{\circ} 16^{\prime} \mathrm{S}$ and longitudes $28^{\circ} 58^{\prime}$ and $29^{\circ} 06^{\prime} \mathrm{E}$. The estimated surface area of the island is $340 \mathrm{~km}^{2}$, spreading $80 \mathrm{~km}$ from north to south and almost $40 \mathrm{~km}$ from east to west. The population has been estimated at 290,000 inhabitants as reported in 2017 [33], with a population density of 647 inhabitants per $\mathrm{km}^{2}$ [34]. Idjwi lies equidistant to the provinces of North Kivu and South Kivu, neighbouring the city of Goma from its northern edge and the city of Bukavu from the southern edge. Service provision to date is very limited, there is no power supply network across the island and safe drinking water only accessible in some areas. Transportation within the island is also precarious since the only roads are unsealed and they become impassable during the rainy season. Small boats connect Idjwi with the main cities on the shore of the mainland and with the neighbouring small islands. 


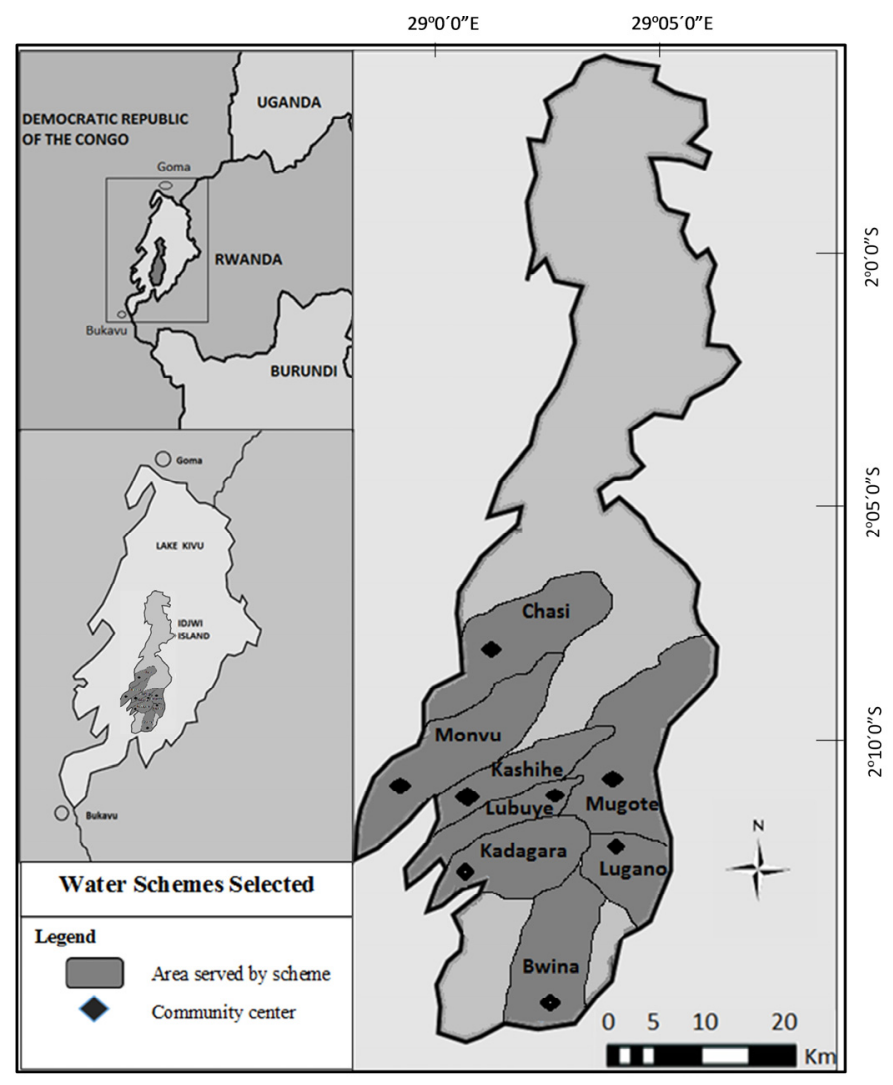

Figure 1. Map of the study area.

As in much of the DRC, the political context in Idjwi has been fragile, as it tries gradually to recover from a series of conflicts that broke out in the 1990s [35]. The DRC remains currently one of the poorest countries in the world [36] where $72 \%$ of the population lives in extreme poverty on less than $\$ 1.90$ a day [37]. According to UNDP, more than $80 \%$ of residents in Idjwi work in the informal sector, living off agriculture, fishing and farming [33]. Eight water schemes on the island were selected for this study: Mugote, Lubuye, Kashihe, Lugano, Monvu, Kadagara, Bwina and Chasi (Figure 1).

These gravity-fed water systems are all based on branched distribution networks. Water is piped down the hill providing part of the yield to scattered public standposts which serve the neighbouring population. The standposts consist of a service connection to the water pipeline, a supporting structure and a tap. Recently, a number of private connections has also been added to the systems.

Relevant features of the water supply systems are summarized in Table 1. Life span of the water schemes can be examined from the construction dates which range from 1989 to 2011. In terms of access, it is worth mentioning that while 32 public water standposts in Mugote serve 1610 households, in Lugano only 24 public standposts serve up to 3228 households, and in Monvu 16 public standposts serve up to 2663 households. 
Table 1. Characteristics of the population and the sample.

\begin{tabular}{ccccc}
\hline Water Schemes & Construction Date & $\begin{array}{c}\text { Number of Public } \\
\text { Standposts }\end{array}$ & $\begin{array}{c}\text { Number of Private } \\
\text { Water Connections }\end{array}$ & Number of Households \\
\hline Mugote & 2006 & 32 & 72 & 14 \\
Lubuye & 2006 & 14 & 3 & 361 \\
Kashihe & 2010 & 11 & 8 & 3228 \\
Lugano & 2005 & 24 & 41 & 2663 \\
Monvu & 1997 & 16 & 15 & 908 \\
Kadagara & 1989 & 16 & 5 & 729 \\
Bwina & 2006 & 5 & 5 & 1744 \\
Chasi & 2011 & 16 & 159 & 11,499 \\
\hline Total & & 134 & \\
\hline
\end{tabular}

\subsection{Data Analysis Framework}

During the last decade, a number of studies eliciting household WTP for water services have emerged [38-42]. This interest responds to a historical lack of specific information on community demand for improved water services in developing countries. In order to implement reliable services it is necessary to gain a better understanding of the economic value assigned by the communities to the improved services [43-45]. It is equally crucial to determine the factors conditioning that value.

In this paper, the concept of WTP refers to the stated price that an individual would accept to pay for avoiding the loss or the diminution of a non-market service [46,47].

The empirical literature on household preferences for water services indicates a great variety of approaches and analytical techniques for measuring WTP. The main two categories are Revealed Preference and Stated Preference. In the Revealed Preference approach, the authors perform experiments or simulate price-response data [48]. In the Stated Preference approach authors employ survey techniques based on hypothetical choices for estimating WTP [49]. Within the Stated Preference option, we can differentiate Direct and Indirect Surveys [50]. To perform Indirect Surveys a ranking procedure is applied [51]. To perform Direct Surveys three elements are involved: a detailed description of the service offered, a description of how the service would be provided and a method for eliciting preferences for the services [42]. The direct approach is referred to as Contingent Valuation (CV) and, despite controversies [52-54], it has become one of the most widely used techniques for valuing non-market goods [48].The present research investigates household preferences for improved water services through a CV survey.

\subsection{Ethics Statement}

Ethical permission was granted from ICLI/RAIDCO Ethics Committee on 16 November 2019 (Project Code: AI.10.01.10.06). All subjects were adults who provided informed oral consent for inclusion before they voluntarily participated in the study.

\subsection{Data Collection Strategies}

\subsubsection{Qualitative Approach}

A qualitative study was performed using primary and secondary sources of information. It aimed at measuring the level of excludability of the water provision services and obtaining a better understanding of the variables to include for the quantitative study. Primary information was gathered through a combination of data collection procedures: key informant interviews and focus group discussions. For this purpose, ten key informant interviews were held at the premises of the implementing agency of water projects in Idjwi (RAIDCO) following a semi-structured protocol. The key informants were selected to contrast the different stakeholder perspectives among local authorities responsible for inspections of the water schemes, water technicians responsible for the management and maintenance of the water systems, social agents in charge of reporting the accounts of the water services, and water committee board members. The information provided 
was related to service provision, water consumption, organisation and management of water resources.

Five focus group discussions were also held at the premises of a local school to gather qualitative information. The discussions took place at an early stage of the field study. The purpose was to appropriately adapt the questions included in the survey and to define the scale to measure the level of excludability. Participants were selected among water system beneficiaries, water committee members, and technicians, differentiating the groups by gender.

Secondary information was gathered from the books of accounts, contracts, recordings of transactions, statements of work and activity reports provided by the local committees. An extensive review of documentary material was also used to prepare the survey questionnaire. Data gathered from document analysis, key informant interviews and focus group discussions was analysed using comparative and thematic content techniques.

\subsubsection{Quantitative Approach}

The elicitation procedure selected for this study consists of an open-ended format questionnaire in which respondents are presented with the benefit of a hypothetical service and are asked for the maximum price to pay for it [55]. This method has been prioritized over the dichotomous choice bidding to avoid final WTP responses to be influenced by the starting bid [56,57] and to lower hypothetical errors [58-60]. The CV survey was implemented through face-to-face interviews based on the structured questionnaire, which had been pretested and checked for internal validity and reliability within a small sample of households. The purpose of the testing was to ensure a clear understanding of the questionnaire by local respondents. Pre-testing results were used to improve the questionnaire accordingly.

The survey was implemented across eight water schemes over a period of four weeks in January 2020. The interviews were carried out by 10 enumerators. They were trained to make respondents feel comfortable and secure. Before participation each interviewee gave oral consent to participate in the anonymous survey on a voluntary basis, on the understanding that he/she could withdraw at any time.

The final version of the survey instrument is comprised of four different sections. In the Section 1, respondents were asked about their water usage. In the Section 2, the $\mathrm{CV}$ is included. The Section 3 included the conditioning factors of WTP obtained from the qualitative analysis. In Section 4 socio-demographic characteristics were processed. The questionnaire was designed in French and later translated into Swahili to be better understood by the participants.

Special attention has been given in the design to validity and reliability. While validity designates the relationship between what is meant to be measured and what is really measured, reliability designates the measurement replicability [52]. In the present study, strategic and hypothetical bias sources were considered [61] for our CV-based estimates to be valid and reliable.

\subsection{Variables}

Qualitative analysis provides us with the conditioning factors of WTP over which the O\&M service agency estimates notable control. Subsequently, such factors are to be employed as independent variables for the quantitative study. Accordingly, six variables were selected: Exclud, Expendit, Meeting, Alternat, Reliable and Time. Table 2 presents the definition of the variables, reasons to be selected and the scale to be categorized under. 
Table 2. Independent variables definition, selection and scale.

\begin{tabular}{|c|c|c|c|}
\hline Variable & Definition & Selection & Scale \\
\hline Expendit & $\begin{array}{l}\text { Level of household expenditure } \\
\text { per month }\end{array}$ & $\begin{array}{l}\text { Households who report a higher expenditure for the } \\
\text { month have more means to pay their water bills [1-3] }\end{array}$ & $\begin{array}{l}\text { 10: more than } 10 \$ * \\
\text { 20/3: between } 31 \text { and } 100 \$ \\
\text { 10/3: between } 10 \text { and } 30 \$ \\
0 \text { : less than } 10 \$\end{array}$ \\
\hline Meeting & $\begin{array}{l}\text { Regular participation in meetings } \\
\text { organized by the water committee }\end{array}$ & $\begin{array}{l}\text { Households who participated regularly in meetings } \\
\text { are more aware of the financial needs of the system [4] }\end{array}$ & $\begin{array}{l}\text { 10: Yes } \\
0: \text { No }\end{array}$ \\
\hline Alternat & $\begin{array}{l}\text { Distance from alternative source } \\
\text { of water to improved system } \\
\text { (standpost) }\end{array}$ & $\begin{array}{l}\text { Household demand for improved water service } \\
\text { depends on existing alternatives }[5,62]\end{array}$ & $\begin{array}{l}\text { 10: alternative located far } \\
\text { away from homestead } \\
\text { 0: alternative located near } \\
\text { homestead }\end{array}$ \\
\hline Reliable & $\begin{array}{c}\text { Rate of Reliability of the } \\
\text { improved system providing safe } \\
\text { water }\end{array}$ & $\begin{array}{l}\text { Reliability of water systems is associated to a financial } \\
\text { cost that users manage to use [6-8] }\end{array}$ & $\begin{array}{l}\text { 10: uninterrupted supply } \\
\text { 30/4: interrupted once } \\
\text { every } 6 \text { months } \\
\text { 20/4: interrupted once } \\
\text { per month } \\
\text { 10/4: interrupted every } \\
\text { second day } \\
\text { 0: non-functional }\end{array}$ \\
\hline Time & $\begin{array}{l}\text { Time employed in fetching water } \\
\text { from improved source }\end{array}$ & $\begin{array}{l}\text { WTP increases if time employed to fetch water is } \\
\text { higher, assuming that opportunity costs will be } \\
\text { optimized }[9,10]\end{array}$ & $\begin{array}{l}\text { 10: over } 60 \mathrm{~min} \\
\text { 20/3: between } 31 \text { and } \\
60 \mathrm{~min} \\
\text { 10/3: between } 10 \text { and } \\
30 \mathrm{~min} \\
\text { 0: less than } 10 \mathrm{~min}\end{array}$ \\
\hline Exclud & $\begin{array}{l}\text { Level of excludability from } \\
\text { accessing improved water system }\end{array}$ & $\begin{array}{c}\text { Households residing in systems with a more exclusive } \\
\text { organization design report higher WTP [11] }\end{array}$ & 0 to 13 \\
\hline
\end{tabular}

* Note: Exchange rates on 1 January 2020: 1 USD = 1683 CDF.

In addition, data gathered from key informant interviews, focus group discussions and technical assessment was also employed to measure the level of excludability for each water scheme. Based on the theory of public goods [63], the level of excludability indicates the ability of a water scheme to exclude non-paying users. Higher levels of excludability are implemented with the intention of preventing queues, wear of the standposts and potential rationing of the water supply. In Idjwi, the water committees are able to administer their own rules and regulations. Some groups prefer to impose tighter regulations and thus, they reduce the number of users. They become more exclusive. In order to measure the levels of excludability, four categories of excludability were analysed in this study: operational, social, physical and managerial [64]. Operational excludability assesses the establishment of water fee prices, payment places and dates, and the functioning of a cashier role. Social excludability weights the establishment of schedules for water usage and the organization of periodical meetings and general assemblies. Physical excludability evaluates the use of locks, fences and water point attendants employed to control the access to services. Managerial factors assess the use of delinquency lists, user directory, accounting books and the adoption of fines and/or exclusion procedures. By quantifying these factors of excludability set in place at the public standposts, the water schemes were classified into three levels of excludability: High (H: 10-13), Moderate (M: 4-9) and Low (L: 0-3) (Table 3). 
Table 3. Factors of excludability quantified for each water scheme.

\begin{tabular}{ccccccc}
\hline $\begin{array}{c}\text { Water } \\
\text { Schemes }\end{array}$ & $\begin{array}{c}\text { Operational } \\
\mathbf{( 0 - 3 )}\end{array}$ & $\begin{array}{c}\text { Social } \\
\mathbf{( 0 - 3 )}\end{array}$ & $\begin{array}{c}\text { Physical } \\
\mathbf{( 0 - 3 )}\end{array}$ & $\begin{array}{c}\text { Managerial } \\
\mathbf{( 0 - 4 )}\end{array}$ & $\begin{array}{c}\text { Total } \\
\text { Number of } \\
\text { Factors }\end{array}$ & $\begin{array}{c}\text { Level of } \\
\text { Excludability }\end{array}$ \\
\hline Mugote & 3 & 3 & 3 & 4 & 13 & $\mathrm{H}$ \\
Lubuye & 2 & 2 & 2 & 2 & 8 & $\mathrm{M}$ \\
Kashihe & 2 & 2 & 2 & 1 & 7 & $\mathrm{M}$ \\
Lugano & 2 & 2 & 2 & 1 & 7 & $\mathrm{M}$ \\
Monvu & 2 & 2 & 2 & 0 & 6 & $\mathrm{M}$ \\
Kadagara & 2 & 2 & 2 & 2 & 8 & $\mathrm{~L}$ \\
Bwina & 1 & 0 & 1 & 0 & 2 & $\mathrm{~L}$ \\
Chasi & 1 & 1 & 0 & 0 & 2 & \\
\hline
\end{tabular}

\subsection{Sample Frame}

The focus of this research is limited to Idjwi Island. Sample population and sample techniques were specifically designed to meet the research objectives (see Table 4). The survey was conducted combining two differentiated sampling techniques. A purposive sampling approach was undertaken to cover the eight water schemes while a systematic sampling approach was undertaken to study the beneficiary households. Each scheme was subdivided into zones of similar population density. Interviewers undertook a set number of interviews for each zone. The interviewers were directed to position themselves at every second standpost along the water scheme. From their locations, they selected households served by the specific standpost at random to survey.

Table 4. Characteristics of the population and the sample.

\begin{tabular}{ccccc}
\hline Water Schemes & $\begin{array}{c}\text { Number of } \\
\text { Households }\end{array}$ & Number of Responses & \% Responses & \% Error \\
\hline Mugote & 1610 & 143 & 8.88 & 7.69 \\
Lubuye & 361 & 142 & 39.34 & 6.41 \\
Kashihe & 256 & 149 & 58.20 & 5.20 \\
Lugano & 3228 & 140 & 4.34 & 8.10 \\
Monvu & 2663 & 144 & 5.41 & 7.94 \\
Kadagara & 908 & 144 & 15.86 & 7.50 \\
Bwina & 729 & 107 & 14.68 & 8.76 \\
Chasi & 1744 & 140 & 8.03 & 7.95 \\
\hline Total & 11,499 & 1109 & 9.64 & 2.80 \\
\hline
\end{tabular}

Note: Error for $95 \%$ confidence level.

\subsection{Statistical Analysis}

Descriptive statistics explored the mean values of WTP and compared the values of factors conditioning WTP for each water scheme. The association between the conditioning factors and the dependent variables $\mathrm{WTP}_{\mathrm{m}}$ (Willingness to pay per month) and $\mathrm{WTP}_{\mathrm{b}}$ (Willingness to pay per bucket, $20 \mathrm{~L}$ ) were preliminary tested using a correlation analysis. Finally, a linear relationship was hypothesized between a log transformed WTP and the predictor variables. The predictive models follow the equation:

$$
\log (Y)=\beta 0+\beta 1 \times X 1+\beta 2 \times X 2+\ldots+\beta n \times X n+\varepsilon
$$

where $\mathrm{Y}$ is the dependent variable, $\mathrm{Xi}$ are the predictor variables and $\beta 0$ is the mean of the response when all predictors are zero. The $\beta$ coefficients measure the influence of each independent variable in the model and $\varepsilon$ the error of the prediction. The candidate variables have been added following a forward stepwise procedure. The fit of the model is calculated measuring the explained variance R2, the F-test, the regression errors and the significance of each $\beta$ coefficient $[65,66]$. Data analysis was performed using IBM SPSS, Version 26.0. (IBM Corp., Armonk, NY, USA). 


\section{Results}

Household characteristics are presented in Table 5. The majority $(72.2 \%)$ of the respondents in the survey were female and roughly two-thirds were aged between 25 and 60 years. Among them, 33.5\% had not received any formal education, less than half had completed primary school, and $21.5 \%$ had completed secondary school or beyond. In terms of occupation nearly two thirds were employed in agriculture, $23 \%$ were employed in trade and only $13.5 \%$ were employed in other sectors. Over $47 \%$ of this sample reported 5 to 8 members in the household.

Table 5. Socio-demographic characteristics of the study sample $(\mathrm{N}=1109)$.

\begin{tabular}{cccccccc}
\hline \multicolumn{2}{c}{ Gender (\%) } & \multicolumn{3}{c}{ Age (\%) } & \multicolumn{3}{c}{ Occupation(\%) } \\
\hline Female & Male & Under 25 & $26-60$ & Over 60 & Agriculture & Trade & Others \\
$801(72)$ & $298(27)$ & $243(22)$ & $754(68)$ & $96(9)$ & $696(62)$ & $262(23)$ & $149(14)$ \\
\hline \multicolumn{2}{c}{ Education Level (\%) } & \multicolumn{2}{c}{ Number of Household Members(\%) } \\
\hline No Formal Education & Primary & Secondary & $2-4$ & $5-8$ & $9-12$ & +12 \\
$371(33)$ & $499(45)$ & $238(21)$ & $245(22)$ & $522(47)$ & $244(22)$ & $95(9)$ \\
\hline
\end{tabular}

A summary of descriptive statistics for the set of variables employed in the study is illustrated on Table 6. Mean $\mathrm{WTP}_{\mathrm{b}}$ has been estimated at $36 \mathrm{CDF}$ and $\mathrm{WTP}_{\mathrm{m}}$ at 327 $\mathrm{CDF}$. These values represent the average estimated willingness to pay for O\&M services of water supply in Idjwi. A significant WTP differential can be observed among water schemes. $\mathrm{WTP}_{\mathrm{m}}$ ranges from $730 \mathrm{CDF}$ in Mugote to $173 \mathrm{CDF}$ in Chasi and 193 in Monvu. $\mathrm{WTP}_{\mathrm{b}}$ ranges from $71 \mathrm{CDF}$ in Kashihe to less than $20 \mathrm{CDF}$ for Lugano, Chasi and Bwina. Additionally significant differences were identified $(\alpha=0.01)$ for the remaining variables. Mean value for Expendit in Chasi is estimated at 0.41, around ten times inferior to the level of expenditure in other schemes such as Lubuye and Mugote. Mean value for Alternat ranges from 7.04 in Kashihe to 0.98 in Chasi. The average level of reliability of the water supply service is estimated at 6.39 in Lubuye and at 0.93 in Chasi.

Table 6. Mean values of $\mathrm{WTP}_{\mathrm{b}}, \mathrm{WTP}_{\mathrm{m}}$ and predictor variables.

\begin{tabular}{ccccccccc}
\hline $\begin{array}{c}\text { Water } \\
\text { Scheme }\end{array}$ & $\mathbf{N}$ & $\mathbf{W T P}_{\mathbf{b}}$ & $\mathbf{W T P}_{\mathbf{m}}$ & Expendit & Alternat & Time & Meeting & Reliable \\
\cline { 3 - 8 } & & Mean (SD) & Mean (SD) & Mean (SD) & Mean (SD) & Mean (SD) & Mean (SD) & Mean (SD) \\
\hline Mugote & 143 & $51.05(51.95)$ & 730.28 & $5.41(2.50)$ & $6.67(4.74)$ & $2.77(2.62)$ & $3.66(4.83)$ & $5.86(2.75)$ \\
Lubuye & 142 & $60.42(64.43)$ & $261.76(175.50)$ & $5.64(2.44)$ & $6.40(4.82)$ & $4.76(2.91)$ & $7.86(4.12)$ & $6.39(2.34)$ \\
Kashihe & 149 & $71.14(125.69)$ & $439.38(350.52)$ & $4.27(3.22)$ & $7.04(4.58)$ & $3.49(2.39)$ & $6.33(4.84)$ & $3.96(2.64)$ \\
Lugano & 140 & $16.87(41.09)$ & $268.71(262.89)$ & $4.22(2.05)$ & $5.64(4.98)$ & $3.36(2.63)$ & $2.88(4.54)$ & $5.02(2.80)$ \\
Monvu & 144 & $27.78(60.70)$ & $193.40(285.79)$ & $2.81(2.85)$ & $4.41(4.99)$ & $3.96(3.37)$ & $4.76(5.01)$ & $5.40(3.75)$ \\
Kadagara & 144 & $25.77(45.38)$ & $287.80(156.15)$ & $4.52(2.00)$ & $5.55(4.99)$ & $2.73(2.70)$ & $4.48(4.99)$ & $4.62(2.06)$ \\
Bwina & 107 & $17.56(28.53)$ & $234.86(226.62)$ & $3.52(2.99)$ & $3.94(4.91)$ & $4.62(2.89)$ & $4.52(5.00)$ & $4.55(3.48)$ \\
Chasi & 140 & $15.32(52.20)$ & $173.93(246.44)$ & $0.41(1.17)$ & $0.98(2.99)$ & $5.24(3.73)$ & $3.77(4.86)$ & $0.93(2.53)$ \\
Total & 1109 & $36.72 * *$ & $327.11^{* *}$ & $3.86^{* *}$ & $5.29 * *$ & $3.84 * *$ & $4.80 *$ & $4.60 * *$ \\
& & $(69.35)$ & $(476.07)$ & $(2.90)$ & $(4.99)$ & $(3.06)$ & $(5.00)$ & $(3.22)$ \\
\hline
\end{tabular}

Note: ${ }^{* *} p<0.01$ in Kruskal-Wallis tests (two-tailed); cell entries are standardized coefficients.

With the purpose of evaluating the strength of the relationships between WTP and its conditioning factors, a correlation analysis in three steps was performed. In the first stage, it is observed that EXCLUD is the variable exerting the greatest influence over $\log \left(\mathrm{WTP}_{\mathrm{b}}\right)$ and $\log \left(\mathrm{WTP}_{\mathrm{m}}\right)$ : significant Pearson correlation indicators for $\alpha=0.01$ of 0.398 and 0.393 (Table 7). Furthermore, all the variables studied have a positive and significant correlation with $\log \left(\mathrm{WTP}_{\mathrm{b}}\right)$ and $\log \left(\mathrm{WTP}_{\mathrm{m}}\right)$. The correlation indicators show that Expendit stands out with values of 0.248 and 0.300 for both outcomes. 
Table 7. Correlation indexes for $\log (\mathrm{WTPb}), \log (\mathrm{WTPm})$ and predictors.

\begin{tabular}{ccc}
\hline Predictors & $\log \left(\mathbf{W T P}_{\mathbf{b}}\right)$ & $\log \left(\mathbf{W T \mathbf { P } _ { \mathbf { m } }}\right)$ \\
\hline Time & $0.130^{* *}$ & $0.089^{* *}$ \\
Reliable & $0.216^{* *}$ & $0.168^{* *}$ \\
Meeting & $0.158^{* *}$ & $0.067^{*}$ \\
Alternat & $0.248^{* *}$ & $0.119^{* *}$ \\
Expendit & $0.248^{* *}$ & $0.300^{* *}$ \\
Exclud & $0.398^{* *}$ & $0.393^{* *}$
\end{tabular}

Note: ${ }^{*} p<0.05$ and ${ }^{* *} p<0.01$ in Pearson correlation tests (two-tailed); cell entries are standardized coefficients.

Having identified significant differences among water schemes for each predictor, in a second step a correlation study classified by water schemes was undertaken. Subsequently, an analysis classified by levels of excludability was also conducted. Results indicate that in Mugote a negative high correlation between $\log \left(\mathrm{WTP}_{\mathrm{b}}\right)$ and Meeting participation was identified (Table 8). In addition, it is described a negative correlation between log $\left(\mathrm{WTP}_{\mathrm{m}}\right)$ and Meeting related to low level of excludability, reaching a -0.472 coefficient in Chasi. However, the correlation between Meeting and $\log \left(\mathrm{WTP}_{\mathrm{b}}\right)$ became positive for the moderate level of excludability, being significant in Kashihe, Lugano, Monvu and Kadagara.

Table 8. Correlation analysis for $\log \left(\mathrm{WTP}_{\mathrm{b}}\right), \log \left(\mathrm{WTP}_{\mathrm{m}}\right)$ classified by water schemes and level of excludability.

\begin{tabular}{|c|c|c|c|c|c|c|c|c|c|c|}
\hline \multirow{2}{*}{$\begin{array}{c}\text { Water } \\
\text { Scheme }\end{array}$} & \multicolumn{5}{|c|}{$\log \left(\mathrm{WTP}_{\mathrm{b}}\right)$} & \multicolumn{5}{|c|}{$\log \left(\mathrm{WTP}_{\mathrm{m}}\right)$} \\
\hline & Time & Reliable & Meeting & Alternat & Expendit & Time & Reliable & Meeting & Alternat & Expendit \\
\hline Mugote & 0.021 & -0.053 & $-0.341^{* *}$ & -0.081 & -0.117 & -0.059 & -0.049 & 0.054 & 0.080 & -0.017 \\
\hline Lubuye & 0.028 & 0.138 & 0.097 & 0.111 & 0.024 & 0.011 & -0.028 & -0.093 & -0.185 * & 0.013 \\
\hline Kashihe & $-0.165 *$ & -0.053 & $0.239^{* *}$ & 0.164 & -0.113 & 0.087 & 0.035 & 0.077 & 0.022 & 0.054 \\
\hline Lugano & 0.141 & -0.094 & $0.269 * *$ & 0.088 & $0.278 * *$ & 0.144 & 0.037 & 0.144 & 0.028 & 0.140 \\
\hline Monvu & -0.073 & -0.079 & 0.296 ** & 0.133 & $-0.193 *$ & $0.255^{* *}$ & -0.161 & -0.061 & $-0.392 * *$ & $0.197^{*}$ \\
\hline Kadagara & -0.148 & $-0.249 * *$ & $0.249 * *$ & -0.079 & 0.163 & -0.194 * & -0.135 & $-0.172 *$ & 0.036 & 0.072 \\
\hline Bwina & -0.053 & 0.032 & 0.018 & -0.188 & -0.131 & 0.039 & 0.050 & 0.142 & $0.280 * *$ & -0.030 \\
\hline Chasi & 0.191 * & 0.018 & -0.007 & -0.094 & 0.075 & $0.611 * *$ & 0.040 & $-0.472 * *$ & 0.143 & 0.163 \\
\hline \multirow{2}{*}{$\begin{array}{l}\text { Level of } \\
\text { Exclud }\end{array}$} & \multicolumn{5}{|c|}{$\log (\mathrm{WTPb})$} & \multicolumn{5}{|c|}{$\log$ (WTPm) } \\
\hline & Time & Reliable & Meeting & Alternat & Expendit & Time & Reliable & Meeting & Alternat & Expendit \\
\hline Total H & 0.021 & -0.053 & $-0.341^{* *}$ & -0.081 & -0.117 & -0.059 & -0.049 & 0.054 & 0.080 & -0.017 \\
\hline Total M & 0.029 & -0.046 & $0.359 * *$ & $0.135^{* *}$ & $0.146^{* *}$ & 0.066 & $-0.110^{* *}$ & 0.018 & -0.037 & $0.166^{* *}$ \\
\hline Total L & 0.076 & $0.137^{*}$ & 0.022 & -0.078 & 0.094 & $0.424^{* *}$ & $0.226^{* *}$ & $-0.270 * *$ & $0.167^{*}$ & $0.271^{* *}$ \\
\hline
\end{tabular}

Note: ${ }^{*} p<0.05$ and ${ }^{* *} p<0.01$ in Pearson correlation tests (two-tailed); cell entries are standardized coefficients.

The variable Reliable has a negative correlation with $\log \left(\mathrm{WTP}_{\mathrm{m}}\right)$ for the moderate level of excludability but shows a positive relationship with $\log \left(\mathrm{WTP}_{\mathrm{b}}\right)$ and $\log \left(\mathrm{WTP}_{\mathrm{m}}\right)$ for the moderate level. The correlation of Expendit with $\log \left(\mathrm{WTP}_{\mathrm{m}}\right)$ is positive and significant for the moderate and high levels of excludability, while the correlation with $\log \left(\mathrm{WTP}_{\mathrm{b}}\right)$ is positive and significant only for the moderate level. Time has a significant correlation with $\log \left(\mathrm{WTP}_{\mathrm{m}}\right)$ for the low level of excludability, highlighting the strength of the relationship for the case of Chasi (0.611). Results also describe a positive correlation for Alternat with $\log \left(\mathrm{WTP}_{\mathrm{b}}\right)$ for the moderate level of excludability and with $\log \left(\mathrm{WTP}_{\mathrm{m}}\right)$ for the low level.

A multi-regression analysis has been conducted to estimate the relationship between WTP and the dependent variables through a predictive model. In a preliminary assessment, the collinearity of the independent variables was analysed. In particular, a principal component regression was performed for this purpose. As a result, the Variables Exclud, Time and Meeting were extracted. These variables explained $63.3 \%$ of the total variance. The remaining variables Reliable, Alternat and Expendit are also significantly correlated with $\log \left(\mathrm{WTP}_{\mathrm{b}}\right)$ and $\log \left(\mathrm{WTP}_{\mathrm{m}}\right)$. However, these predictors are simultaneously correlated for $\alpha=0.01$ with Exclud showing correlation indexes of 0.331 for Reliable, 0.252 for Alternat and 0.428 for Expendit. Therefore, they have been excluded from the models [66]. 
A linear multi-regression model with logarithmic transformations (log-linear model) was selected to explain the variables $\mathrm{WTP}_{\mathrm{b}}$ and $\mathrm{WTP}_{\mathrm{m}}$. A forward stepwise procedure has been conducted. In both cases, the regression analyses are significant for $\alpha=0.01$ with $F$ values of 93.222 and 130.093. The values of $R^{2}$ are acceptable (0.193 and 0.205) considering the complexity of the study, the number of independent variables in each regression (two and three), the significance of the $\beta$ coefficients and the number of cases used in the analysis [67].

As expected from the correlation analysis, Exclud exerts the strongest influence on the independent variables. In the first step, this variable exerts a positive influence on log $\left(\mathrm{WTP}_{\mathrm{b}}\right)$ explaining $15.6 \%$ of its variance with a $\beta$ coefficient value of 0.098 (Table 9). In the second and third step, the inclusion of the variables Meeting and Time improves the model, increasing the explained variance from $15.6 \%$ to $20.5 \%$ but the $\mathrm{F}$ value decreases notably from 201.041 to 93.222 . In this final model, the $\beta$ coefficients are 0.101 for Exclud, 0.035 for Meeting and 0.018 for Time.

Table 9. Predictive models for $\log \left(\mathrm{WTP}_{\mathrm{b}}\right)$ and $\log \left(\mathrm{WTP}_{\mathrm{m}}\right)$.

\begin{tabular}{|c|c|c|c|c|c|c|c|c|c|c|c|c|c|}
\hline \multirow[b]{2}{*}{ Variable } & \multicolumn{6}{|c|}{$\log \left(W_{T P}\right)$} & \multirow[b]{2}{*}{ Variable } & \multicolumn{6}{|c|}{$\log \left(W_{T} P_{m}\right)$} \\
\hline & $\mathbf{R}^{2}$ & F & $\begin{array}{l}\text { Model } \\
\text { Sig. }\end{array}$ & S.E. & $\beta$ & $\begin{array}{l}\text { Variable } \\
\text { Sig. }\end{array}$ & & $\mathbf{R}^{2}$ & F & $\begin{array}{l}\text { Model } \\
\text { Sig. }\end{array}$ & S.E. & $\beta$ & $\begin{array}{l}\text { Variable } \\
\text { Sig. }\end{array}$ \\
\hline $\begin{array}{l}\text { Constant } \\
\text { Exclud }\end{array}$ & 0.156 & 201.04 & 0.000 & 0.742 & $\begin{array}{l}0.314 \\
0.098\end{array}$ & $\begin{array}{l}0.000 \\
0.000\end{array}$ & $\begin{array}{l}\text { Constant } \\
\text { Exclud }\end{array}$ & 0.162 & 209.43 & 0.000 & 0.523 & $\begin{array}{l}1.801 \\
0.070\end{array}$ & $\begin{array}{l}0.000 \\
0.000\end{array}$ \\
\hline $\begin{array}{l}\text { Constant } \\
\text { Exclud } \\
\text { Meeting }\end{array}$ & 0.200 & 136.07 & 0.000 & 0.722 & $\begin{array}{l}0.156 \\
0.097 \\
0.034\end{array}$ & $\begin{array}{l}0.004 \\
0.000 \\
0.000\end{array}$ & $\begin{array}{l}\text { Constant } \\
\text { Exclud } \\
\text { Time }\end{array}$ & 0.193 & 130.09 & 0.000 & 0.513 & $\begin{array}{l}1.625 \\
0.077 \\
0.034\end{array}$ & $\begin{array}{l}0.000 \\
0.000 \\
0.000\end{array}$ \\
\hline $\begin{array}{l}\text { Constant } \\
\text { EXCLUD } \\
\text { MEETING } \\
\text { TIME }\end{array}$ & 0.205 & 93.22 & 0.000 & 0.720 & $\begin{array}{l}0.055 \\
0.101 \\
0.035 \\
0.018\end{array}$ & $\begin{array}{l}0.420 \\
0.000 \\
0.000 \\
0.013\end{array}$ & & & & & & & \\
\hline
\end{tabular}

Modelling $\log \left(\mathrm{WTP}_{\mathrm{m}}\right)$ the variable Exclud explains $16.3 \%$ of the variance. The variable Time is included in the second step. It increases the R2 from 0.162 to 0.193 but it decreases the $\mathrm{F}$ value from 209.425 to 130.093 . However, it should be highlighted that the significance level of the variables is 0.000 . The variable Meeting is not included in the model because its influence is not significant in the third step. The coefficients $\beta$ are positive in the two steps. The value of $\beta$ for the variable Exclud in the first step is 0.070 and its influences increases up to 0.077 in the second step. The value of $\beta$ for the variable Time is 0.034 .

Accordingly, to these results the predictive models for $\log \left(\mathrm{WTP}_{\mathrm{b}}\right)$ and $\log \left(\mathrm{WTP}_{\mathrm{m}}\right)$ follow the equations:

$$
\begin{gathered}
\log \left(\mathrm{WTP}_{\mathrm{b}}\right)=0.055+0.101 \times \text { Exclud }+0.035 \times \text { Meeting }+0.018 \times \text { Time } \\
\log \left(\mathrm{WTP}_{\mathrm{m}}\right)=1.625+0.077 \times \text { Exclud }+0.034 \times \text { Time }
\end{gathered}
$$

\section{Discussion}

The financial viability of rural water O\&M services relies largely on sustained community's revenue collection. Current development models endorse partial cost recovery for O\&M services through co-financing strategies shared by donors, local governments and community members. The design of appropriate water tariffs is key to sustained user payments in the long term. To achieve this it is of paramount importance to evaluate community demand for the services offered and to establish the economic value that households place on such services.

This study elicits household WTP for O\&M services across eight water schemes. The results of the investigation reveal three important insights. First, the average economic value that community members in Idjwi assign to regular O\&M services of the improved water systems has been estimated at $327 \mathrm{CDF}$ per month. The findings show a notable $\mathrm{WTP}_{\mathrm{m}}$ differential among studied schemes of up to $420 \%$. Reported $\mathrm{WTP}_{\mathrm{m}}$ estimates range 
from 730 CDF in Mugote to 174 CDF in Chasi. These estimates indicate the household preferences for acceptable services at each water scheme. These values allow us to understand the level of payment that water users from local schemes feel able or willing to afford. This information on local demand for improved services is of great importance for regulation authorities in order to establish acceptable water tariffs.

A significantly high rate of beneficiaries from the water systems reported demand for payable O\&M services. Over $92 \%$ of respondents showed their preference for an improved source and indicated their intention to pay for O\&M services. Evidence suggest that revenue collection systems are more likely to be sustainable if user contribution rates exceeds a $60 \%$ threshold [1], showing the potential for water schemes in Idjwi to achieve stable revenue collection systems. However, there often exists a mismatch between communities expressing demand for improved systems and their payment behaviour for true costs [68]. International agencies reveal that, across DRC, only around $21 \%$ of the interventions maintain an operational system of water tariffs ten years after implementation [9].

Moreover, the total revenue collected from user contributions when applying the stated preferred monthly fee of 327 CDF would be far from guaranteeing full life-cyclecost recovery for the water schemes on the island. Documentary data from the studied schemes show that in recent years some major repairs have exceeded a cost of 20 million CDF. However, in the design of cost-sharing arrangements, that ICLI and RAIDCO are in the process of implementing, water tariffs are planned to only cover minor repairs and preventative maintenance while major repairs, rehabilitations and replacements should be covered by a mix of revenue from government subsidies and donor support. Only if the new water tariffs are acceptable and affordable, could the revenue collected from user payments be sustained in the long term and contribute to the financial viability of the water systems.

Second, the design of alternative payment options may play an important role in establishing tariffs affordable for all, including the poorest. The average stated WTP per bucket has been estimated at $36 \mathrm{CDF}$, ranging from $71 \mathrm{CDF}$ in Kashihe to $15 \mathrm{CDF}$ in Chasi. This option implies a higher fee per liter of water (e.g., the total expenditure in water for a household of five members considering a consumption of one bucket per person per day would result in $1100 \mathrm{CDF}$ per month). However, this option is more practicable for households in informal economies who struggle to gather the amount necessary for a monthly payment in a single installment. Most residents in Idjwi do not work in salaried positions [33] thus they are obliged to manage their money on a day-to-day basis [69]. The pay-per-bucket mode offers people with limited financial resources an opportunity to make use of the service on a day-to-day basis.

Third, findings reveal three primary determinants of households' WTP for O\&M services in Idjwi. The predictive model is mainly determined by the level of excludability to access improved water sources, the participation of beneficiaries in management meetings organised by the water committee and the level of monthly expenditure per household.

Despite proximity in geographical terms and despite having been implemented by the same agency in similar organizational designs, schemes have evolved towards different forms of management. Collective nature of management of water services has translated into user groups opting for different levels of excludability to provide long-term functioning of the water points. Previous studies suggested that applying public goods theory to communal management of water services could serve as an appropriate framework of assessment. Koehler [64] reported that the institutional design of the water schemes as clubs (i.e., higher level of excludability) or as common pools (i.e., lower level of excludability) could influence payment behaviour. In Idjwi more exclusive groups have imposed tighter financial regulations to generate the required revenue. They have achieved this through membership fees, joining fees, fines and stricter enforcement mechanisms. Beneficiaries from systems with exclusive forms of management show higher average WTP per month than more inclusive groups. The results of this study suggest that in Idjwi a more exclusive form of management is related to higher user payment levels. 
In the same way, the results also imply that households that spend more time fetching water from an improved source are more likely to report a higher WTP for O\&M. Key informants informed that due to current deficiencies in O\&M services many water points became non-functional. Community members served at those water points were pushed to walk further searching for an improved source. Thus, they have seen their time employed in fetching water increase considerably. Users who require more time to fetch water are willing to pay higher water fees in order to improve O\&M services and to re-establish functioning water points.

Additionally, participation in meetings held by the water committees results in a higher WTP among participants. During the focus group discussions, some actors suggested that community members who regularly participate in informative and managerial gatherings with the committees become more aware of the financial challenges faced by the systems and accordingly report stronger preferences for O\&M services.

In this study several potential limitations have been identified. The unique social, cultural and political landscape of Idjwi Island limits potential generalization of the findings. The team of enumerators for the survey was recruited from amongst technicians employed at the water provider. This may have influenced community behaviour despite strict ethical policies. To minimize the impact, each enumerator was assigned to survey a water scheme different from the scheme they regularly work at. Protest votes and yea-sayers were not identified with additional questions, which could introduce downward bias into WTP estimates. Finally, there are also concerns about potential strategic and hypothetical biases associated with the CV method survey. Strategic bias in this investigation appears because respondents may deliberately formulate their answers to influence the outcome of the study in their own interest [70]. Hypothetical bias appears because there is no real purchase of the service, which generally turns into an overestimation of WTP [71]. Being aware of these issues, it is necessary to be conservative with the estimates and associated implications.

\section{Conclusions}

The findings of this study contribute to develop an improved understanding of users' WTP for O\&M services in Idjwi Island (DRC). The evidence illustrated here is that communities in Idjwi report a high demand for the operation and maintenance services of the water systems. The economic value that beneficiaries of the systems assign to improved services is of $327 \mathrm{CDF}$ per month. A substantial $\mathrm{WTP}_{\mathrm{m}}$ differential has been observed among household respondents from different water schemes. It is worth noting that a significant proportion of users would benefit from a pay-per-bucket mode, despite the increase in the fee up to $36 \mathrm{CDF}$ per bucket. Results also reveal that the level of excludability from accessing the systems, the participation in management meetings and the time employed in fetching water from an improved source are contingent with WTP.

A better understanding of local demand on O\&M services in Idjwi is of paramount importance for NGOs and development agencies working in the region. In an attempt to achieve financial sustainability, key agents will make use of these findings to set water tariffs that can be practicable, acceptable and affordable for all.

Author Contributions: Conceptualization, R.J.-R.; Data curation, R.J.-R. and G.A.-L.; Formal analysis, R.J.-R. and G.A.-L.; Funding acquisition, R.J.-R.; Investigation, B.L.; Methodology, G.A.-L.; Project administration, B.L.; Resources, B.L. and J.L.; Software, G.A.-L.; Writing-original draft, R.J.-R.; Writing-review and editing, J.L. All authors have read and agreed to the published version of the manuscript.

Funding: This research was funded by ICLI and the University of the Basque Country.

Institutional Review Board Statement: The study was conducted according to the guidelines of the Declaration of Helsinki, and approved by ICLI/RAIDCO Ethics Committee on 16 November 2019 (Project Code: AI.10.01.10.06).

Informed Consent Statement: Informed consent was obtained from all subjects involved in the study. 
Data Availability Statement: The data presented in this study are available on request from the corresponding author.

Acknowledgments: The authors would like to thank Idjwi Water Authorities for supporting the work reported above. The findings and conclusions expressed in this paper though, represent exclusively those of the authors. We wish to thank RAIDCO for supplying data and the Water Council for sharing knowledge during the field component of this research. Financial support was provided by ICLI and the University of the Basque Country. We would also extend our gratitude to A. Antonas and ICLI board members for their valuable contributions.

Conflicts of Interest: The authors declare no conflict of interest.

\section{References}

1. Foster, T. A critical mass analysis of community-based financing of water services in rural Kenya. Water Resour. Rural. Dev. 2017, 10, 1-13. [CrossRef]

2. Hope, R.; Thompson, P.; Koelher, J.; Foster, T. Rethinking the economics of rural water in Africa. Oxf. Rev. Econ. Policy 2020, 36, 171-190. [CrossRef]

3. WHO. The Guidelines: A Framework for Safe Drinking Water. Guidelines for Drinking Water Quality, 3rd ed.; WHO: Geneva, Switzerland, 2008.

4. Marks, S.J.; Onda, K.; Davis, J. Does sense of ownership matter for rural water system sustainability? Evidence from Kenya. J. Water Sanit. Hyg. Dev. 2013, 3, 122-133. [CrossRef]

5. Giné, R.; Pérez-Foguet, A. Sustainability assessment of national rural water supply program in Tanzania. Nat. Resour. Forum 2008, 32, 327-342. [CrossRef]

6. Hope, R. Is community water management the community's choice? Implications for water and development policy in Africa. Hydrol. Res. 2014, 17, 664-678. [CrossRef]

7. Thomson, P.; Koehler, J. Performance-oriented Monitoring for the Water SDG—Challenges, Tensions and Opportunities. Aquat. Procedia 2016, 6, 87-95. [CrossRef]

8. Kwangware, J.; Mayo, A.; Hoko, Z. Sustainability of donor-funded rural water supply and sanitation projects in Mbire district, Zimbabwe. Phys. Chem. Earth 2014, 76, 134-139. [CrossRef]

9. UNICEF. Global Evaluation of UNICEF's Drinking Water Supply Programming in Rural Areas and Small Towns 2006-2016; United Nations Children's Fund: New York, NY, USA, 2018.

10. UN General Assembly. Transforming Our World: The 2030 Agenda for Sustainable Development; UN General Assembly: New York, NY, USA, 2015; A/RES/70/1.

11. UNDESA. Global Sustainable Development Report; United Nations Department of Economic and Social Affairs: New York, NY, USA, 2014.

12. UN General Assembly. The Human Right to Water and Sanitation; UN General Assembly: New York, NY, USA, 2010; A/RES/64/292.

13. Marks, S.J.; Kumpel, E.; Guo, J.; Bartram, J.; Davis, J. Pathways to sustainability: A fuzzy-set qualitative comparative analysis of rural water supply programs. J. Clean. Prod. 2018, 205, 789-798. [CrossRef]

14. Harvey, A.; Reed, R. Community-managed water supplies in Africa: Sustainable or dispensable? Community Dev. J. 2006, 42, 365-378. [CrossRef]

15. Herrera, V. Reconciling global aspirations and local realities: Challenges facing the Sustainable Development Goals for water and sanitation. World Dev. 2019, 118, 106-117. [CrossRef]

16. Carter, R.; Harvey, E.; Casey, V. User financing of rural hand pump water services. In Proceedings of the IRC Symposium 2010, Pumps, Pipes and Promises, The Hague, The Netherlands, 16-18 November 2010.

17. Whaley, L.; Cleaver, F. Can 'functionality' save the community management model of rural water supply? Water Resour. Rural. Dev. 2017, 9, 56-66. [CrossRef]

18. Montgomery, M.A.; Bartram, J.; Elimelech, M. Increasing Functional Sustainability of Water and Sanitation Supplies in Rural Sub-Saharan Africa. Environ. Eng. Sci. 2009, 26, 1017-1023. [CrossRef]

19. Barnes, R.; Ashbolt, N.; Roser, D.; Brown, P. Implementing sustainable water and sanitation projects in rural, developing communities. Waterlines 2014, 33, 71-88. [CrossRef]

20. Ying, Y.; Skilling, H.; Banerjee, S.; Wodon, Q.; Foster, V. Cost Recovery Equity and Efficiency in Water Tariffs Evidence from African Utilities; World Bank: Washington, DC, USA, 2010.

21. Bartram, J.; Brocklehurst, C.; Bradley, D.; Muller, M.; Evans, B. Policy review of the means of implementation targets and indicators for the sustainable development goal for water and sanitation. Clean Water 2018, 1, 3. [CrossRef]

22. Fischer, A.; Hope, R.; Manandhar, A.; Hoque, S.; Foster, T.; Hakim, A.; Islam, S.; Bradley, D. Risky responsibilities for rural drinking water institutions: The case of unregulated self-supply in Bangladesh. Glob. Environ. Chang. 2020, 65, 102152. [CrossRef]

23. Schweitzer, R.W.; Mihelcic, J.R. Assessing sustainability of community management of rural water systems in the developing world. J. Water Sanit. Hyg. Dev. 2012, 2, 20-30. [CrossRef]

24. Satterthwaite, D. Missing the Millennium Development Goal targets for water and sanitation in urban areas. Environ. Urban. 2016, 28, 99-118. [CrossRef] 
25. De Albuquerque, C. On the Right Track Good Practices in Realizing the Rights to Water and Sanitation; ERSAR-Entidade Reguladora dos Serviços de Águas e Resíduos: Lisbon, Portugal, 2012; ISBN 978-989-8360-09-0.

26. Emenike, C.; Tenebe, I.; Omole, D.; Ngene, B.; Oniemayin, B.; Maxwell, O.; Onoka, B. Accessing safe drinking water in sub-Saharan Africa: Issues and challenges in South-West Nigeria. Sustain. Cities Soc. 2017, 30, 263-272. [CrossRef]

27. Joint Monitoring Programme. Progress on Drinking Water and Sanitation; WHO: Geneva, Switzerland; UNICEF: New York, NY, USA, 2014

28. WSSCC. WASH Post 2015 Proposed Targets and Indicators for Drinking-Water Sanitation and Hygiene; WHO: Geneva, Switzerland; UNICEF: New York, NY, USA, 2014.

29. WaterAid. Mapping the Relationship Between Water Hygiene and Sanitation and HIV/AIDS; Water Aid: Addis Ababa, Ethiopia, 2011.

30. Vásquez, W.F.; Espaillat, R. Willingness to pay for reliable supplies of safe drinking water in Guatemala: A referendum contingent valuation study. Urban Water J. 2016, 13, 284-292. [CrossRef]

31. Jubin, A. Willingness to pay for access to improved and reliable piped water: A contingent valuation study in Kerala, India. Thail. Stat. 2019, 17, 75-83.

32. Jiang, Y.; Rohendi, A. Domestic water supply, residential water use behaviour, and household willingness to pay: The case of Banda Aceh, Indonesia after ten years since the 2004 Indian Ocean Tsunami. Environ. Sci. Policy 2018, 89, 10-22. [CrossRef]

33. UNDP. Human Development Report 2019 Inequalities in Human Development in the 21st Century Democratic Republic of the Congo; UNDP: New York, NY, USA, 2019.

34. Thomson, D.; Hadley, M.; Greenough, P.; Castro, M. Modelling strategic interventions in a population with a total fertility rate of 8.3: A cross-sectional study of Idjwi Island. BMC Public Health 2012, 12, 959.

35. World Bank. World Development Indicators.2015. Available online: http://data.worldbank.org/country/congo-dem-rep (accessed on 11 April 2021).

36. World Bank. The World Bank in DRC. 2020. Available online: https://www.worldbank.org/en/country/drc/overview (accessed on 11 April 2021).

37. ADB. African Economic Outlook 2020 Developing Africa's Workforce for the Future; African Development Bank Group: Abidjan, Cote d'Ivoire, 2020.

38. Vásquez, W.F.; Mozumder, P.; Hernández-Arce, J.; Berrens, R.P. Willingness to pay for safe drinking water: Evidence from Parral, Mexico. J. Environ. Manag. 2009, 90, 3391-3400. [CrossRef] [PubMed]

39. Akhtar, S.; Dean, S.; Anjum, F.; Javed, M.; Sana, A.; Sarah, D.; Faiza, A.; Maryam, J. Determination of Willingness to Pay for Improved Water Supply in Selected Areas of Lahore. Chin. J. Urban Environ. Stud. 2018, 6. [CrossRef]

40. Brouwer, R.; Job, F.C.; Van Der Kroon, B.; Johnston, R. Comparing Willingness to Pay for Improved Drinking-Water Quality Using Stated Preference Methods in Rural and Urban Kenya. Appl. Heal. Econ. Heal. Policy 2014, 13, 81-94. [CrossRef] [PubMed]

41. Aslam, H.; Liu, J.; Mazher, A.; Mojo, D.; Muhammad, I.; Fu, C. Willingness to Pay for Improved Water Services in Mining Regions of Developing Economies: Case Study of a Coal Mining Project in Thar Coalfield, Pakistan. Water 2018, 10, 481. [CrossRef]

42. Byambadorj, A.; Lee, H.S. Household Willingness to Pay for Wastewater Treatment and Water Supply System Improvement in a Ger Area in Ulaanbaatar City, Mongolia. Water 2019, 11, 1856. [CrossRef]

43. Keough, A.; Vásquez, W.F. Willingness-to-pay for water resource protection in El Salvador. Water Environ. J. 2020, 34, 192-206. [CrossRef]

44. Briand, A.; Lare-Dondarini, A. Demand for urban water services: An analysis of willingness to pay of households in Bamako and in precarious districts of Ouagadougou. Rev. Econ. Reg. Urbaine 2017, 1, 33-64.

45. Makwinja, R.; Kosamu, I.B.M.; Kaonga, C.C. Determinants and Values of Willingness to Pay for Water Quality Improvement: Insights from Chia Lagoon, Malawi. Sustainability 2019, 11, 4690. [CrossRef]

46. OECD. Cost-Benefit Analysis and the Environment: Recent Developments Willingness to Pay vs. Willingness to Accept; OECD: Paris, France, 2006. [CrossRef]

47. Haie, N. Transparent Water Management Theory: Sefficiency in Sequity; Springer: Berlin, Germany, 2020. [CrossRef]

48. Balistreri, E.; McClelland, G.; Poe, G.; Schulze, W. Can Hypothetical Questions Reveal True Values? A Laboratory Comparison of Dichotomous Choice and Open-Ended Contingent Values with Auction Values. Environ. Resour. Econ 2001, 18, 275-292. [CrossRef]

49. Burt, Z.; Njee, R.M.; Mbatia, Y.; Msimbe, V.; Brown, J.; Clasen, T.F.; Malebo, H.M.; Ray, I. User preferences and willingness to pay for safe drinking water: Experimental evidence from rural Tanzania. Soc. Sci. Med. 2017, 173, 63-71. [CrossRef]

50. Blumenschein, K.; Blomquist, G.C.; Johannesson, M.; Horn, N.; Freeman, P. Eliciting Willingness to Pay Without Bias: Evidence from a Field Experiment. Econ. J. 2007, 118, 114-137. [CrossRef]

51. Islam, M.; Akber, A.; Islam, A. Willingness to pay for improved drinking water in southwest coastal Bangladesh. Water Supply 2018, 19, 1-10. [CrossRef]

52. Carson, R.T.; Flores, N.E.; Meade, N.F. Contingent Valuation: Controversies and Evidence. Environ. Resour. Econ. 2001, 19, 173-210. [CrossRef]

53. Rodríguez-Tapia, L.; Revollo-Fernández, D.A.; Morales-Novelo, J.A. Household's Perception of Water Quality and Willingness to Pay for Clean Water in Mexico City. Economies 2017, 5, 12. [CrossRef]

54. Mould, J.; Contreras, I.; Garduño, J.; Salinas, G. The willingness-to-pay concept in question. Rev. Saude Publica 2009, 43, 352. [CrossRef] [PubMed] 
55. Whittington, D. Improving the Performance of Contingent Valuation Studies in Developing Countries. Environ. Resour. Econ. 2002, 22, 323-367. [CrossRef]

56. Kaliba, A.R.M.; Norman, D.W.; Chang, Y.-M. Willingness to pay to improve domestic water supply in rural areas of Central Tanzania: Implications for policy. Int. J. Sustain. Dev. World Ecol. 2003, 10, 119-132. [CrossRef]

57. Naiga, R.; Penker, M. Determinants of users' willingness to contribute to safe water provision in rural Uganda. Lex Localis J. Local Self Gov. 2014, 12, 695-714. [CrossRef]

58. Pravesh, T.; Sebak, J. Willingness to pay for improved water services: A case of Darjeeling, India. Asian J. Water Environ. Pollut. 2017, 14, 51-59.

59. Polyzou, E.; Jones, N.; Evangelinos, K.; Halvadakis, C. Willingness to pay for drinking water quality improvement and the influence of social capital. J. Socio Econ. 2011, 40, 74-80. [CrossRef]

60. Sakketa, T.G.; Prowse, M. Women, Wealth and Waterborne Disease: Smallholders' Willingness to Pay for a Multiple-Use Water Scheme in Ethiopia. J. Dev. Stud. 2017, 54, 426-440. [CrossRef]

61. Van Der Pol, M.; Shiell, A.; Au, F.; Johnston, D.; Tough, S. Convergent validity between a discrete choice experiment and a direct, open-ended method: Comparison of preferred attribute levels and willingness to pay estimates. Soc. Sci. Med. 2008, 67, 2043-2050. [CrossRef] [PubMed]

62. Schouten, T.; Moriarty, P. Scaling up the community management of rural water supply. Waterlines 2004, 23, 2-4. [CrossRef]

63. Ostrom, E. Beyond Markets and States: Polycentric Governance of Complex Economic Systems. Am. Econ. Rev. 2010, 100, 641-672. [CrossRef]

64. Koehler, J.; Thomson, P.; Hope, R. Pump-Priming Payments for Sustainable Water Services in Rural Africa. World Dev. 2015, 74, 397-411. [CrossRef]

65. Weisberg, S. Applied Linear Regression; John Wiley \& Sons: Hoboken, NJ, USA, 2005; Volume 528.

66. Cohen, J.; Cohen, P.; West, S.G.; Aiken, L.S. Applied Multiple Regression/Correlation Analysis for the Behavioral Sciences; Routledge: London, UK, 2013.

67. Faul, F.; Erdfelder, E.; Buchner, A.; Lang, A.-G. Statistical power analyses using G*Power 3.1: Tests for correlation and regression analyses. Behav. Res. Methods 2009, 41, 1149-1160. [CrossRef]

68. Carter, R.C.; Tyrrel, S.F.; Howsam, P. The Impact and Sustainability of Community Water Supply and Sanitation Programmes in Developing Countries. Water Environ. J. 1999, 13, 292-296. [CrossRef]

69. Collignon, B.; Vezina, M. Independent Water and Sanitation Providers in African Cities; UNDP-World Bank Water and Sanitation: Washington, DC, USA, 2020.

70. Van Houtven, G.L.; Pattanayak, S.K.; Usmani, F.; Yang, J.-C. What are Households Willing to Pay for Improved Water Access? Results from a Meta-Analysis. Ecol. Econ. 2017, 136, 126-135. [CrossRef]

71. Le Gall-Ely, M. Definition, Measurement and Determinants of the Consumer's Willingness to Pay: A Critical Synthesis and Avenues for Further Research. Rech. Appl. Mark. 2009, 24, 91-112. [CrossRef] 